Pavlo VEGERA ${ }^{1}$

Roman KHMIL

Zinoviy BLIKHARSKYY ${ }^{3}$

\title{
THE SHEAR STRENGTH OF REINFORCED CONCRETE BEAMS WITHOUT SHEAR REINFORCEMENT
}

\begin{abstract}
In this article the results of experimental investigations of reinforced concrete (RC) beams on the shear strength are presented. Tests are performed by the improved methodology with testing every beam twice. All experiments are conducted considering different shear span to effective depth ratio. This makes for establishing the impact of the force application position on the carrying capacity of reinforced concrete beams without transverse reinforcement. The result showed the increase of carrying capacity by $8-10 \%$ while reducing the shear span to effective depth ratio from $d / a=2$ to $d / a=1,5$ and $18-20 \%$ while ratio was $d / a=1$. Calculations by the current standards in different countries showed low compliance with experiment, which is negative for economic design. Carrying capacity calculation method for reinforced concrete beams without shear reinforcement considering loading accommodations as proposed and tested. This factor is not taken into account in Ukrainian current norms of reinforced concrete structures designing. The deviation between theoretical calculation by the proposed empirical formula and experimental data is $10 \%$ which provides sufficient reliability of the results for future using.
\end{abstract}

Keywords: shear span to effective depth ratio, shear calculation.

\section{Statement of a problem}

Reinforced concrete elements are most common structures in the world. Exploring their stress strain state is a necessary task placed before researchers. Special attention should be paid to the changes in structure's performance

\footnotetext{
${ }_{1}$ Author for correspondence: Pavlo Vegera postgraduate student; Lviv National Polytechnic University; Ukraine, 79013, Lviv, S. Bandera Street, 12; PavloVegera@gmail.com.

${ }^{2}$ Roman Khmil PhD associate professor; Lviv National Polytechnic University; Ukraine, 79013, Lviv, S. Bandera Street, 12; roman_hl@ukr.net.

${ }^{3}$ Zinoviy Blikharskyy professor; Lviv National Polytechnic University; Ukraine, 79013, Lviv, S. Bandera Street, 12., blikharskyy@ukr.net
} 
depending on the changes in the loading application place. In this case, the greatest danger is concrete beams with considerable shear effort. These elements collapse suddenly. Their critical state can be determined only while making detailed diagnostics of inclined cracks. Researching shear strength of flexural concrete elements and their shear strengthening methods are actual problems that were studied by many researchers [2-4], which describes urgency of the issue.

\section{The aim and the objective of a research}

In this article authors explain the following:

- determine the influence of load location on the shear carrying capacity of reinforced concrete beams without transverse reinforcement;

- review current and determine optimum relationship for RC beams shear carrying capacity calculation ;

- compare the theoretical values with the experimental.

\section{Experimental data and tests results}

\subsection{Materials and prototypes design}

To achieve the aim of research a sample of concrete beam with $2100 \mathrm{~mm}$. length, $100 \mathrm{~mm}$ width, and $200 \mathrm{~mm}$ height was selected. As beam's tension reinforcement A400C $\varnothing 18 \mathrm{~mm}$ rebar was chosen (according to DSTU 3760:2006). A400C Ø10 mm rebar (according to DSTU 3760:2006) was chosen as compressed reinforcement. Constructive transverse reinforcement - A240C Ø $6 \mathrm{~mm}$ rebar (DSTU 3760:2006) located in the area without transverse force (Fig. 1,2).

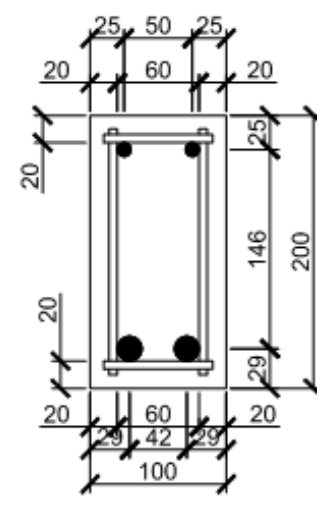

Fig. 1. Cross section of the sample

Rys. 1. Przekrój poprzeczny próbki 


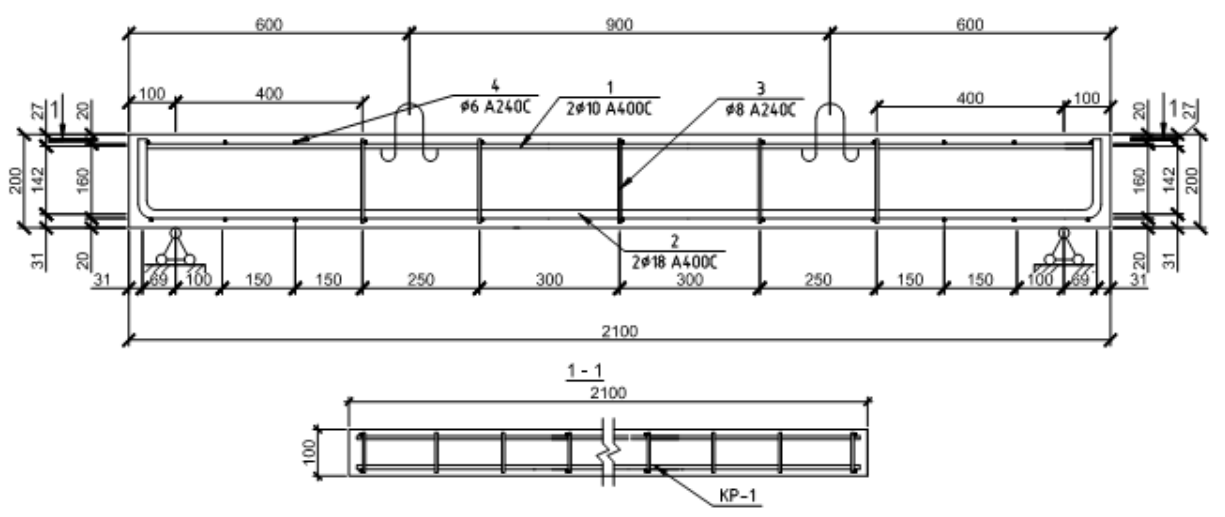

Carcass KP-1

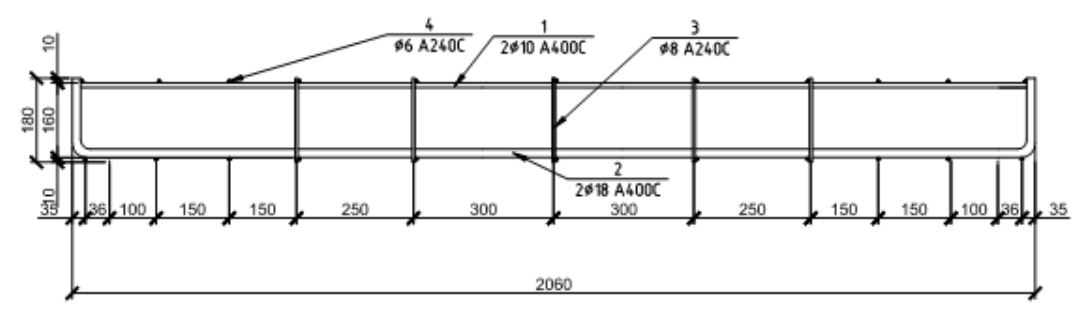

Fig.2. Reinforcement and dimensions of the designed beam

Rys. 2. Zbrojenie i wymiary projektowanej belki

Reinforced concrete beam was designed to provide flexural bearing capacity according to recommendations [5-6].

\subsection{The program and research methodology}

Research was performed on 3 samples. Each sample was tested twice by specially developed technique, which allowed to get the results of high convergence. Variable parameter was shear span to effective depth ratio which equaled $\mathrm{a} / \mathrm{d}=2 ; \mathrm{a} / \mathrm{d}=1,5 ; \mathrm{a} / \mathrm{d}=1$; where $\mathrm{a}$ - the distance from the support to the point of force application, $\mathrm{d}$ - effective depth of prototypes. The load applied through the distribution traverse using hydraulic jacks incrementally. Each increment equaled $10 \%$ of the expected destructive value. Load level was controlled by a ring dynamometer. After each increment, the instrument readings were taken. Reinforcement and concrete deformations were measured using dial indicators with value of units $0,001 \mathrm{~mm}$. (see. Fig. 3). 


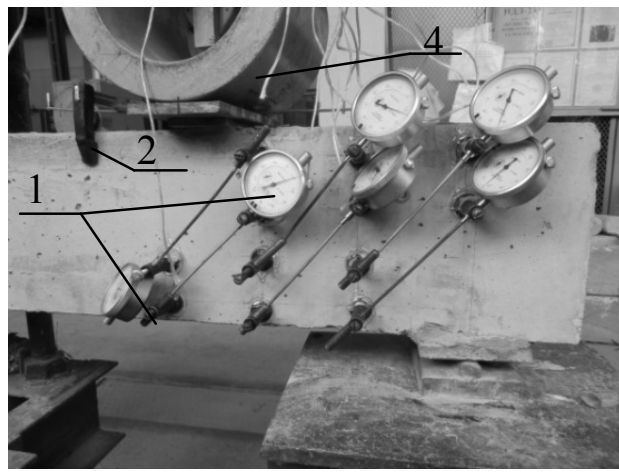

a)

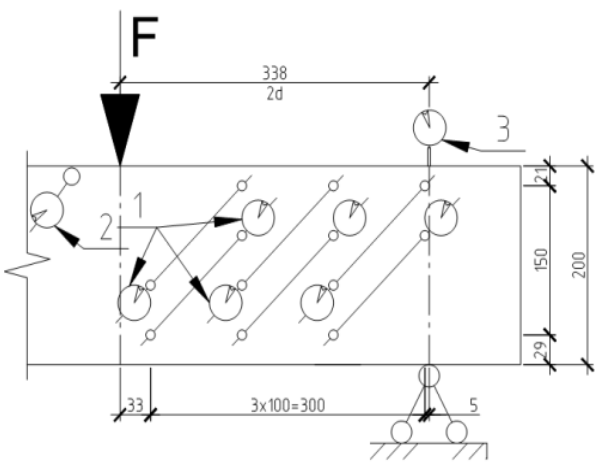

b)

Fig.3. The placement of measuring devices: a) placement of devices on experimental sample; b) the layout of dial indicators; 1 - dial indicators for deformations measurement; 2 - indicator Aistova; 3 - holders for dial indicators; 4 - ring dynamometer

Rys. 3. Rozmieszczenie urządzeń pomiarowych: a) rozmieszczenie urządzeń na próbce badawczej; b) układ czujników zegarowych; 1 - czujniki zegarowe do pomiaru deformacji; 2 - czujnik Aistova; 3 - uchwyty czujników zegarowych ; 4 - siłomierz kabłąkowy

Tests performed similarly for each section of the investigated beams at different shear span to effective depth ratio. Beams marking were as follows: BO beam ordinary, the first digit - serial number, the second digit - prototypes number, the third digit - section number. For example BO 1.2-2 means that tested example from first series of the second beam of the second section.

\subsection{Results of experiments.}

Received values of reinforced concrete beams shear carrying capacity showed a slight deviation - the difference between one type of test was less than $6 \%$ (see. Table. 1 ).

Table.1. Main parameters of experiment

Tabela 1. Główne parametry badań

\begin{tabular}{|c|c|c|c|c|c|}
\hline $\begin{array}{l}\text { Types } \\
\text { of the } \\
\text { beams }\end{array}$ & $\begin{array}{c}\text { Cross } \\
\text { section } \\
\text { bxh }[\mathrm{mm}]\end{array}$ & $\begin{array}{c}\text { Span of the } \\
\text { beam } \mathrm{I}_{0} \\
{[\mathrm{~mm}]}\end{array}$ & $\begin{array}{l}\text { Shear span to } \\
\text { depth ratio, a/d }\end{array}$ & $\begin{array}{c}\text { Experimen- } \\
\text { tal shear } \\
\text { load, }[\mathrm{kN}]\end{array}$ & \begin{tabular}{|c|} 
The discre- \\
pancy between \\
twins, [\%]
\end{tabular} \\
\hline BO 1.1-1 & \multirow{2}{*}{$201 \times 106$} & 1900 & 2 & 165 & \multirow{2}{*}{4,2} \\
\hline BO 1.1-2 & & 1550 & 2 & 172 & \\
\hline BO 1.2-1 & \multirow{2}{*}{ 199x98 } & 1900 & 1 & 192 & \multirow{2}{*}{6,3} \\
\hline BO 1.2-2 & & 1750 & 1 & 204 & \\
\hline BO 1.3-1 & \multirow{2}{*}{$202 \times 98$} & 1900 & 1,5 & 180 & \multirow{2}{*}{3,3} \\
\hline BO 1.3-2 & & 1650 & 1,5 & 186 & \\
\hline
\end{tabular}


The shear strength of reinforced concrete beams without shear reinforcement 451

As we can see beams shear strength increases with decreasing shear span to depth ratio. The absolute increase of carrying capacity is $40 \mathrm{kN}$, which is slightly more than $17 \%$ (see. Table. 2 ).

Table.2. Main parameters of experimental

Tabela 2. Główne parametry badań

\begin{tabular}{|c|c|c|c|c|}
\hline $\begin{array}{c}\text { Types } \\
\text { of the beam }\end{array}$ & $\begin{array}{c}\text { Compressive } \\
\text { strength } \\
\text { of concrete, [MPa] }\end{array}$ & $\begin{array}{c}\text { Carrying } \\
\text { capacity, } \\
{[\mathrm{kN}]} \\
\end{array}$ & $\begin{array}{c}\text { Average value, } \\
{[\mathbf{k N}]}\end{array}$ & $\begin{array}{c}\text { Carrying ca- } \\
\text { pacity increas, } \\
{[\%]}\end{array}$ \\
\hline BO 1.1-1 & \multirow{2}{*}{40} & 165 & \multirow{2}{*}{168,5} & \multirow{2}{*}{-} \\
\hline BO 1.1-2 & & 172 & & \\
\hline BO 1.2-1 & \multirow{2}{*}{40} & 192 & \multirow{2}{*}{198} & \multirow{2}{*}{17,5} \\
\hline BO 1.2-2 & & 204 & & \\
\hline BO 1.3-1 & \multirow{2}{*}{40} & 180 & \multirow{2}{*}{183} & \multirow{2}{*}{8,6} \\
\hline BO 1.3-2 & & 186 & & \\
\hline
\end{tabular}

Also note that the physical destruction of reinforced concrete beams with a smaller $\mathrm{d} / \mathrm{a}$ ratio occurred with significant chipping of concrete around inclined cracks and longitudinal reinforcement (see Fig. 4).

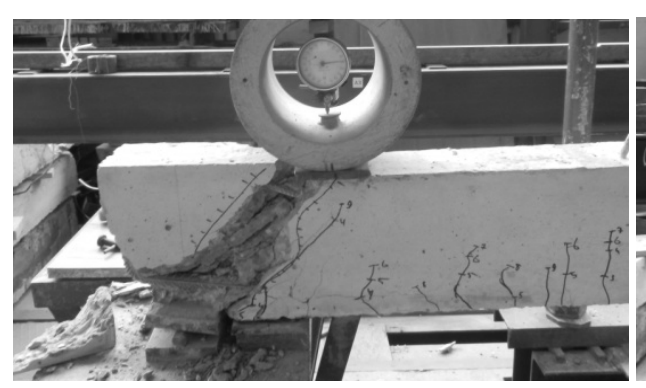

a)

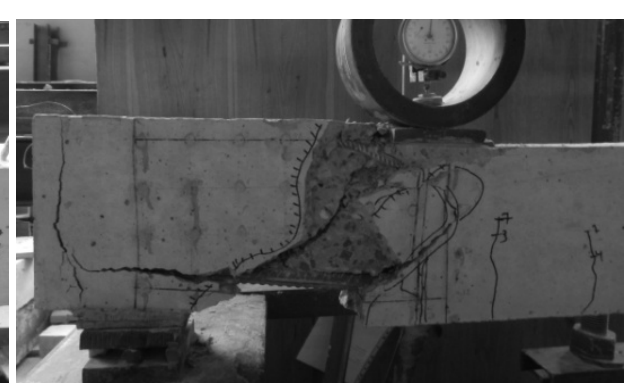

b)

Fig.4. Experimental elements destruction types: a) with a relative cut $\operatorname{span} \mathrm{a} / \mathrm{d}=1$; b) with a relative cut $\operatorname{span} \mathrm{a} / \mathrm{d}=2$

Rys. 4. Typy zniszczenia elementów badanych: a) ze względnym zasięgiem strefy ścinanej a/d=1;

b) ze względnym zasięgiem strefy ścinanej $\mathrm{a} / \mathrm{d}=2$

Such type destruction associated with the construction reinforcement. Longitudinal reinforcement has a sturdy fixed. It perceives significant proportion of stresses in concrete until destruction of the compressed concrete area. This type of destruction refers to Type 2 - the destruction of shear force. Longitudinal reinforcement prevents the rotation parts of concrete around the end of the inclined cracks. Two parts of elements are shifted relative to each other. 


\section{Theoretical calculation of reinforced concrete beams shear strength.}

\subsection{Calculation of shear strength with difference relative cut span by basic formulas in different countries design codes}

According to the current Ukrainian design codes [5-6] and European [7] shear calculation of reinforced concrete beams without transverse reinforcement conducted by the following relationship:

$$
V_{R d, c 1}=\left[C_{R d, c} \cdot k \cdot\left(100 \cdot \rho_{1} \cdot f_{c k}\right)^{\frac{1}{3}}+k_{1} \cdot \sigma_{c p}\right] \cdot b_{w} \cdot d
$$

but value is not less than

$$
V_{R d, c 2}=\left(V_{\min }+k_{1} \cdot \sigma_{c p}\right) \cdot b_{w} \cdot d
$$

where: $C_{R d, c}=0,18 / \gamma_{c}$ - the minimum value (normalized) of shear strength for concrete, [MPa];

$k=1+\sqrt{200 / d} \leq 2,0$ - size effect factor;

$k_{1}=0,15$ - coefficient which depends on the diameter of the longitudinal reinforcement;

$\rho_{1}$ - coefficient of reinforcing cross-section by the longitudinal tensile reinforcement;

$f_{c k}$ - characteristic value of concrete compressive strength at 28 days, [MPa];

$\sigma_{c p}$ - the concrete compressive stress at the centroidal axis due to axial loading and/or prestressing, [MPa];

$b_{w}, d$-respectively smallest cross section width in the tensile zone and efficiently depth of cross section, $\mathrm{mm}$;

$$
V_{\min }=0,035 \cdot k^{3 / 2} \cdot f_{c k}^{1 / 2},[\mathrm{MPa}] \text {. }
$$

As we can see the relationships (1), (2) have any prerequisites for consideration type and load location - shear span to effective depth ratio. These equations determine the carrying capacity with considerable reserve. Cross section, which strength is considered, calculated without taking into account location along the span of the beam.

Determination of carrying capacity according to USA design codes [1] carried out using relationship:

$$
V_{c}=2 \cdot \sqrt{f_{c}^{\prime}} \cdot b_{w} \cdot d
$$

where: $f_{c}^{\prime}$ - characteristic value of concrete compressive strength at 28 days, [psi]. 
The shear strength of reinforced concrete beams without shear reinforcement 453

This equation does not consider the influence of longitudinal reinforcement, and the impact of shear span to effective depth ratio, but it allows you to quickly assess the carrying capacity of reinforced concrete beams on the shear.

Australian rules AS 3600-2009 [8] contained calculation by the formula:

$$
V_{u c}=\beta_{1} \cdot \beta_{2} \cdot \beta_{3} \cdot b_{w} \cdot d \cdot f_{c v} \cdot \sqrt[3]{\frac{A_{s t}}{b_{w} \cdot d}}
$$

where: $\beta_{1}=1,1 \cdot\left(1,6-\frac{d}{1000}\right) \geq 1,1$ - size effect factor;

$\beta_{2}=1$ for beams without axial tension;

$\beta_{3}=\frac{2 \cdot d}{a_{v}} \leq 2-$ shear span to depth ratio;

$f_{c v}=\sqrt[3]{f_{c}^{\prime}} \leq 4-$ shear concrete strength, $\mathrm{MPa} ;$

$A_{s t}$ - area of tensile reinforcement, $\mathrm{mm}$.

This equation more fully includes all factors. But the result is much diminished when compared with experiment data. Rules [9], which allowed performing the calculation of carrying capacity of reinforced concrete beams on the shear, with using engineering techniques, use relationship:

$$
Q=\frac{\varphi_{b 4} \cdot\left(1+\varphi_{n}\right) \cdot R_{b t} \cdot b \cdot h_{0}^{2}}{c}
$$

where: $\varphi_{b 4}=1,5$ - coefficient of working conditions for heavy concrete;

$\varphi_{n}=0$ - coefficient, which taking into account influence of concrete compressive stress at the centroidal axis due to axial loading and/or prestressing;

$R_{b t}$ - design value of concrete strength on axial tensile, MPa;

$b, h_{0}$ - respectively smallest cross section width in the tensile zone and efficiently depth of cross section, mm.;

$c$ - the distance from the point of application of force to support, $\mathrm{mm}$.

This technique is based on taking into account tensile strength of concrete, but overlooked longitudinal reinforcement element.

Listed analyzing the methods of calculation can conclude that Australian norms take into account all the factors of the shear strength. Other calculation methods have disadvantages which are manifested in ignoring several factors or their significant simplification. Therefore, the studies of methods of calculation require further investigation. 


\subsection{Comparison of different calculation methods results.}

To compare considered methods of shear strength calculation, they were conducted to determine the carrying capacity of experimental samples. The results of calculations are presented in Table. 3 .

Table.3. Results of reinforced concrete beams shear strength calculation

Tabela 3. Wyniki obliczeń nośności na ścinanie zbrojonej belki żelbetowej

\begin{tabular}{|c|c|c|c|c|c|c|c|}
\hline \multirow{2}{*}{$\begin{array}{l}\text { Types of } \\
\text { the beams }\end{array}$} & \multirow{2}{*}{$\begin{array}{c}\text { Cross } \\
\text { section } \\
\text { bxh }[\mathbf{m m}]\end{array}$} & \multirow{2}{*}{$\begin{array}{c}\text { Shear span } \\
\text { to effective } \\
\text { depth ratio, } \\
\text { a/d }\end{array}$} & \multirow{2}{*}{$\begin{array}{c}\text { Experi- } \\
\text { mental } \\
\text { shear } \\
\text { strength, } \\
{[\mathrm{kN}]}\end{array}$} & \multicolumn{4}{|c|}{$\begin{array}{l}\text { The theoretical value of carrying ca- } \\
\text { pacity calculated by the method, [kN] }\end{array}$} \\
\hline & & & & 1 & 2 & 3 & 4 \\
\hline BO 1.1 & 20 & 2 & 168,5 & & & & 34,55 \\
\hline BO 1.2 & 199x98 & 1 & & 20 & $1,0 /$ & 59,4 & 63,35 \\
\hline BO 1.3 & $202 \times 98$ & 1,5 & 183 & 20,83 & 21,45 & 39,6 & 42,76 \\
\hline
\end{tabular}

Analyzing data from the table. 3 we can say that all techniques significantly underestimate the results of shear carrying capacity of reinforced concrete beams over $50 \%$. This is due to calculation shear strength in the most unfavorable case. Shear strength at least insufficient anchoring of the longitudinal reinforcement and worst shear span to effective depth ratio. Using these equations in the design leads to significant overspending materials.

\subsection{Calculation of carrying capacity with difference relative cut span by improved calculation method.}

Given the rules of calculation [5] proposes to improve the method of calculation to include parameter in relationship which takes into account the shear span to effective depth ratio. Whereas increasing distance to the point of application force, carrying capacity of beams on the shear decreases, so proposed to consider in the formula (1), taking into account a/d ratio in the form:

$$
V_{R d, c}=\left[\left(\frac{6 \cdot d}{a}\right)^{1 / 3} \cdot C_{R d, c} \cdot\left(1+\sqrt{\frac{200}{d}}\right) \cdot\left(100 \cdot \rho_{1} \cdot f_{c k}\right)^{2 / 3}\right] \cdot b_{w} \cdot d
$$

Such a formula includes basic parameters to fully determine the carrying capacity of concrete elements on the shear strength.

Calculation with this empirical formula shows significantly better convergence in results (about 10\%) and shows the importance of stable results compared with experimental data (see. Table. 4). It should also be noted that the calculation was conducted using coefficient $\gamma_{c}=1,5$ for main combi- 
The shear strength of reinforced concrete beams without shear reinforcement 455

nation of factor loadings (then $C_{R d, c 1}=0,12 \mathrm{MPa}$ ) and emergency one $\gamma_{c}=1,2\left(C_{R d, c 2}=0,15 \mathrm{MPa}\right)$, which are encouraged to accept according to [7].

Table.4. Results of reinforced concrete beams shear strength calculation

Tabela 4. Wyniki obliczeń nośności na ścinanie zbrojonej belki żelbetowej

\begin{tabular}{|c|c|c|c|c|c|}
\hline $\begin{array}{l}\text { Types of } \\
\text { the beams }\end{array}$ & $\begin{array}{c}\text { Experi- } \\
\text { mental } \\
\text { value, } \\
V_{R d, c}, \\
{[\mathbf{k N}]}\end{array}$ & $\begin{array}{c}\text { Theoretical } \\
\text { value by } \\
\text { main combi- } \\
\text { nation, } V_{R d, c 1} \\
{[\mathbf{k N}]}\end{array}$ & $\begin{array}{c}\left(\frac{V_{R d, c}}{V_{R d, c 1}}-1\right) \times \\
\quad \times 100 \%\end{array}$ & $\begin{array}{c}\text { Theoretical } \\
\text { value by } \\
\text { emergency } \\
\text { combina- } \\
\text { tion, } V_{R d, c 2} \\
{[\mathbf{k N}]}\end{array}$ & $\begin{array}{c}\left(\frac{V_{R d, c}}{V_{R d, c 2}}-1\right) \times \\
\quad \times 100 \%\end{array}$ \\
\hline BO 1.1 & 168,5 & 152,1 & 10,8 & 175,4 & $-3,9$ \\
\hline BO 1.2 & 198 & 186,4 & 6,2 & 233,0 & $-15,0$ \\
\hline BO 1.3 & 183 & 163,1 & 12,2 & 203,8 & $-10,2$ \\
\hline
\end{tabular}

For a visual comparison of the obtained results by the proposed calculation method with results by existing methods see. Fig.4. In this figure are dependent theoretical shear strength of beams for the main type of load. However, it should be noted that if this be interpreted as a total load of emergency communication load that the convergence of our methods will be the same and is about $10 \%$. But as the theoretical values are higher than experimental data, this interpretation requires the application of special conditions of experimental studies, which would be modeled sudden and dynamic character of the emergency application load.

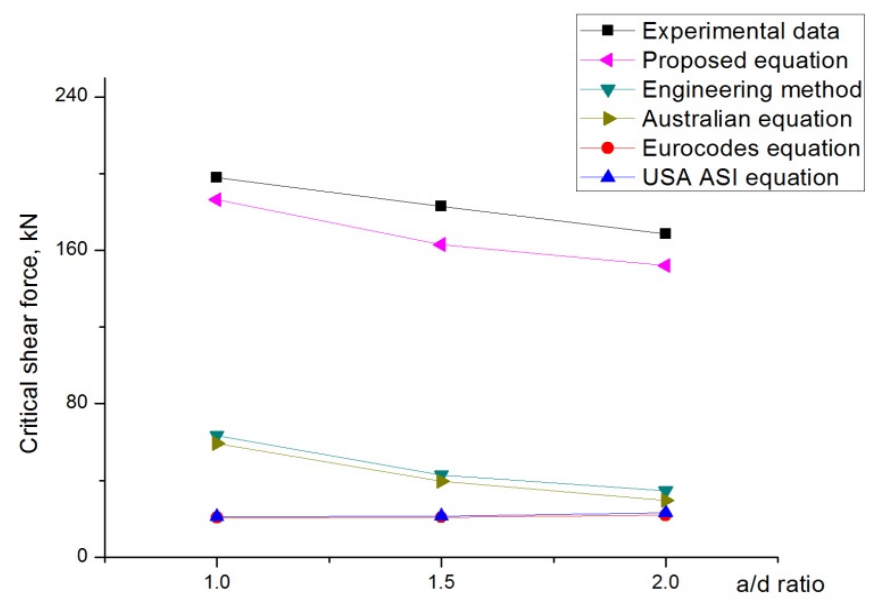

Fig.5. Graphics comparison of difference method of calculation results

Rys. 5. Graficzne porównanie wyników obliczeń według różnych metod 


\section{Conclusions.}

Based on the above material the following conclusions can be drawn:

1. Shear Carrying capacity of the beams without transverse reinforcement increases with decreasing $\mathrm{d} / \mathrm{a}$ ratio. This can be considered for more effective design of concrete elements.

2. Results of shear strength calculating according to different methods show significantly lower values than experiment.

3. Proposed improved theoretical equation, produced the results with deviation from experimental data about $15 \%$. This result is stable at all investigation of shear span to effective depth ratio which suggests sufficient efficacy of this empirical relationship.

\section{Bibliogaphy}

[1] ACI Committee 318, Reinforced concrete design manual (ACI 318-08) Version 12. Berkeley, California: American Concrete institute, 2010.

[2] Bazant Z.P., Kazemi M.T. Size effect on diagonal shear failure of beams without stirrups. ACI Structural journal. Vol.88 №3. pp.268-276. 1991.

[3] Chavan R.S., Pawar P.M. Shear strength of slender reinforced concrete beams without web reinforcement. Journal of engineering research and application. Vol.3, Issue 6. pp. 554-559. 2013.

[4] Elahi A., Effect of Reinforcement Ratio and Shear Span on Shear Strength of High-Strength Concrete Beams. MSc Thesis, Taxila University, 2003.

[5] DBN B.2.6 -98 : 2009 Concrete and reinforced concrete construction. Minbudrehion Ukraine , Kyiv, 2011.

[6] DSTU B.V.2.6-156 : 2010 Concrete and reinforced concrete construction with heavy concrete. Minbudrehion Ukraine, Kyiv, 2011.

[7] EN 1992-1-1:2004 (E) Eurocode 2: Design of concrete structures - Part 1-1: General rules for buildings. Brussels, GEN, 2004.

[8] Loo Y.C., Chowdhury S.H. Reinforced and prestressed concrete. Analysis and design with emphasis on the application of AS 3600-2009. Cambridge university press, USA, 2010.

[9] SNIP 2.03.01-84 * Concrete and concrete structures. NIIZHB State Building USSR, Moscow, 1986. 
The shear strength of reinforced concrete beams without shear reinforcement 457

NOŚNOŚĆ NA ŚCINANIE BELEK ŻELBETOWYCH BEZ ZBROJENIA NA ŚCINANIE

\section{Streszczenie}

W artykule zaprezentowano wyniki badań doświadczalnych nośności na ścinanie żelbetowych (RC) belek. Badania zostały przeprowadzone według ulepszonej metodologii, weryfikując wyniki każdej belki dwukrotnie. Wszystkie badania przeprowadzono przy uwzględnieniu różnych zakresów strefy ścinanej w stosunku do efektywnej wysokości przekroju. W ten sposób określono wpływ pozycji przyłożenia siły nośność belek żelbetowych bez zbrojenia poprzecznego. Wyniki badań wykazały wzrost nośności o 8-10\% gdy stosunek zakresu strefy ścinanej do wysokości efektywnej d/a maleje z 2 do 1,5 i 18-20\% gdy stosunek ten był d/a $=1$. Przeprowadzone obliczenia nośności na ścinanie według obowiązujących norm z różnych krajów pokazał małą zgodność z wynikami badań, co negatywnie wpływa na ekonomiczne projektowanie elementów. Zaproponowano i sprawdzono eksperymentalnie metodę obliczania nośności żelbetowych belek bez zbrojenia na ścinanie uwzględniającą miejsce przyłożenia obciążenia. Czynnik ten nie jest brany pod uwagę w aktualnych ukraińskich normach projektowych konstrukcji żelbetowych. Różnice między wynikami obliczeń teoretycznych według proponowanego wzoru empirycznego a wynikami badań doświadczalnymi wynosi $10 \%$, co potwierdza wystarczającą dokładność i przydatność do przyszłego użycia.

Słowa kluczowe: współczynnik zasięgu strefy ścinanej do wysokości efektywnej przekroju, obliczanie ścinania

Przestano do redakcji:26.05.2015

Przyjęto do druku: 10.01.2016

DOI: $10.7862 / \mathrm{rb} .2015 .209$ 